FOONG Ping

\title{
Producing Shu Culture: Why Painters Needed Court Titles in Tenth-Century Sichuan
}

\section{Introduction}

The government bureaucracy's system of official ranks and titles is a rich source for studying spatial imagination in middle period China. This is because titular hierarchy and its vocabulary intrinsically construct space, which in turn reflect power relations within the imperial city and beyond. As is well known, titles do not simply describe daily function. Nor does rank always precisely coincide with post. Instead, a dual-ranking system expressed personal rank status separately from one's actual job. Articulated in long and complicated sequences, titles provide information about salary levels and other aspects of official service - for example, education and mode of entry into service, and career ladders prescribed according to individual prestige that enabled routine promotions. Different types of titles, held in parallel with personal rank, indicated someone's work as a commission or duty assignment. ${ }^{1}$

Artists were interlopers within this highly competitive system and signs of their participation is therefore intriguing. The population of makers in an imperial city ranged from unskilled laborers to workshop craftsmen to technocrats who provided their skills as support staff. Of this last group, only calligraphers and painters concern us below. These two fields of artistic practice held differing amounts of prestige in middle period China. As the most literate of the technocrats, calligraphers were the most likely to crossover and be awarded titles usually held by the bureaucracy's regular officers. Professional painters generally came from families of lower social standing and could not qualify for careers as officials, but top painters occasionally held official titles too. These titles therefore contain rich information for evaluating their social and institutional status. From the Tang dynasty onwards, painters' titles were for the most part sinecures - nominal commissions having little to do with their painting ability. The titles may have provided a stipend above what they received in

1 For an introduction to the structure of the Song dynasty civil service, see Charles Hartman, "Sung Government and Politics." In Chaffee, John W. and Denis Twitchett, eds., The Cambridge History of China, Volume 5, Part Two: Sung China, 960-1279 (Cambridge: Cambridge University Press, 2009), 19-138, see pages 49-80.

Ә Open Access. ( 2022 FOONG Ping, published by De Gruyter. (c) BY-NC-ND This work is licensed under the Creative Commons Attribution-NonCommercial-NoDerivatives 4.0 International License. 
their regular position as artists. In any case, the extent to which the hierarchies of officialdom flexed to recognize certain artists is a little-studied phenomenon with broad implications for the roles that they played in political culture.

This paper considers title sequences held by Sichuanese painters from the kingdom of Shu in comparison with their Tang-dynasty predecessors. We first focus on key titles awarded to the 9th-century court painter Cheng Xiuji 程修已 (804-63), and those of Lü Yao 呂羨 (9th century) and Zhu Qian 竹虔 (9th century) who served at the capital cities of both Tang and Shu. Parallels and departures between Tang and Shu practice emerge when we juxtapose these Tang painters against Shu painters active a century later. It becomes clear that Sichuan's rulers regularized stipendiary titles for their court painters to a greater extent, and likely had their own motivations for rewarding artists in this manner. The following analysis suggests that, by the 10th century, titular awards formalized Sichuan's painting styles and family traditions as cultural products distinct to this geographic region. This articulation of cultural distinction expressed the independence and regional power of Shu rulers just before Song reunification.

\section{Painters' titles and their significances}

When rulers use titles to acknowledge the value of court artists, these titles become a rich resource for examining conditions of court patronage. Painters' titles contain concrete data for quantifying one type of status: not personal social standing, but rather an individual's institutional status accorded through official channels of recruitment, education, rank, and promotion. Such processes recognize artists as bureaucratic functionaries, as elements in the machinery of government. A title offers not only economic recompense but can also show an artist's service as a constituent element of a ruler's authority. By examining the titles that artists were permitted or prohibited, we better understand the roles art played in representing legitimate rule. In short, titles provide an opportunity to study institutional patronage on its own terms rather than as an individual's patronage and collecting pathology - writ large.

One feature of institutional patronage is worthy of deep scrutiny. From the Tang dynasty onwards, top court calligraphers and painters were occasionally raised above their peers with titular privileges commonly awarded to regular officials of the bureaucracy. For government officers, a variety of titles denote different prize categories: some titles provide monetary stipends whereas others offer the recipient a higher rank status than their actual, official rank. For a professional painter, this form of superlative recognition was exceedingly rare 
since the two worlds could not be further apart. It almost goes without saying that painters rarely had the required education or family background to take advantage of such privileges - no matter if their access to the official rewards system was only temporary, provisional, or informal in nature.

If we take as a given that rulers regularly cultivated art and culture as a figure for dynastic stability, it is equally important to acknowledge that their purpose was not simply lavish expenditure. Titles are a principal means for a ruler (and his agents) to incorporate artists into a courtly establishment, and they therefore signify official endorsement of certain artistic styles or traditions that those artists represent. Titles define court-approved standards. They form the basis for building a tangible form of cultural power - a literal product that could then be deployed as a component of state diplomacy.

This was the case for Huang Quan 黃鉒 (903?-965), by far our best recorded middle-period painter for the titles he received. According to written sources, he was a highly versatile professional painter who was excellent in multiple genres - bird-and-flower, landscape, and figural subjects - each being specializations that require very different skills. In Sichuan before the Song conquest, he provided distinguished service under the Meng regime of the Shu kingdom. While serving the second ruler of Later Shu 後蜀 (934-65), Meng Chang 孟甫 (b. 919, r. 934-65), Huang Quan's paintings cultivated interregional diplomacy and trade with neighboring kingdoms in the Yangzi region. As I have demonstrated elsewhere, he received four official titles during the 10th century and each title further enhanced the ability of his art to function as state gifts. He likely gained these entitlements due to some combination of his artistic and administrative talents, but especially because his art came to serve official purposes for Shu's rulers. ${ }^{2}$

Why do high titles with no substantive duties - in essence empty titles merit our consideration? First of all, we must accept that designations without an attached job are valuable to study, that sinecures are meaningful. This recognition doesn't come easily because there are few more challenging problems than the complex workings of the bureaucracy's ranking system. A second factor that presents a challenge in this project is that our sample is inherently small: painters rarely received ranked official titles. They much more often held unranked titles related to their function, the most long-lived being the prestigious Hanlin daizhao 翰林待詔 (Expectant Official of the Hanlin) denoting

2 Huang Quan's titular recognition is discussed in Foong Ping, "On rulers and painters: Issues of institutional patronage and transmitted hierarchies," conference paper for the panel, "National Committee on the History of Art State of the Field: New Frontiers in Chinese Art." College Art Association, 102nd Annual Conference, Chicago, 2014. 
various types of top servitors awaiting the emperor's summons at the Hanlin Academy (Hanlinyuan 翰林院).

Highly recognized painters were occasionally extended sumptuary benefits that belonged to the highest echelons of regular officers. The most notable and conspicuous of these benefits was official regalia known as "purple with gold fishpouch” 紫金魚袋, which were honors normally designating high ministers Rank 3 and up. In Sichuan, Huang Quan received his purple robes after 926 CE from the founder of Later Shu, Meng Zhixiang 孟知祥 (879-934, r. 934). Huang’s second son Huang Jubao 黄居寶 (dates unclear), also a noted calligrapher, and fifth son Huang Jucai 黄居寀 (933-ca. 993) were both conferred "purple with gold fishpouch." Presumably, the sons were extended this honor based not only on their own successes but with regard to their father's achievement. In some respects, the rationale behind providing formal recognition to the Huang lineage with official robes is reminiscent of yin privilege 蔭補, the right of high officials to protect their families by directly appointing sons to office.

Huang Quan's fifth son Huang Jucai later served the first Song dynasty emperors and they awarded him a civil-service prestige title (san guan 散官) as Grand Master for Court Audiences (Chaoqing daifu 朝請大夫). To be sure this title denoted a relatively modest Rank $5 \mathrm{~b} 1$ at level twelve of twenty-nine levels, but it was nevertheless a personal rank within the regular bureaucracy. ${ }^{3}$ Given to all men who enter official service, a prestige title fixes one's rank status and assures a state emolument (grain allowance, money, provisions etc.) regardless of whether one is in active service with a commission or inactive. Huang Jucai's $5 \mathrm{~b} 1 \mathrm{rank}$ gained him the associated state emolument but also a place during court audiences alongside others within the civil-service hierarchy - a rare and considerable honor for a professional painter. But why did Song emperors reward this Sichuan painter in this way? It does not suffice to describe the awards held by either Huang Quan or his sons as anomalous special treatment, merely a matter of royal largess.

\footnotetext{
3 The prestige title Grand Master for Court Audiences (Chaoqing daifu 朝請大夫) was held by civil-service officers, see Gong Yanming 龔延明, Songdai guanzhi cidian 宋代官制辭典. (Dictionary of Song dynasty official titles) (Beijing: Zhonghua shuju, 1997), 561. In the early Northern Song, the two types of prestige titles - civil and military - each had twenty-nine ranks. See Gong Yanming 30 and 31, Table 10 and Table 11, for lists of these civil prestige titles and military prestige titles, respectively.
} 


\section{Some nomenclature of official service for artists}

A brief notice on the structural means for retaining artists at court is important to establish before going further. Men with different social backgrounds, specializations, and skill levels received different treatment. From Tang dynasty onwards, libraries and some other government agencies engaged scribes, copyists, illustrators, and other technical sub-officials as professional support staff. Posts at an agency were marked, for instance, with the suffix $z h i$ 直, meaning to “take up duty.” Men of learning 學士 charged with compiling imperially sponsored scholarly works in the Academy of Scholarly Worthies (Jixiandian shuyuan 集賢殿書院) had use of both shuzhi 書直 and huazhi 畫直, writers on clerical duty and illustrators on painting duty, respectively. ${ }^{4}$

Also during the Tang, men with calligraphic ability above that needed for clerical work were shishu 侍書 (Attendant Calligrapher). This title comprises the word shi 侍, “to serve," hence describes someone's function as calligrapher. ${ }^{5}$ Some calligraphers also held a nominal title providing the appointee with a rank grade and the associated salary. Perhaps because calligraphers were regularly called to teach the art form to princes and other members of the royal family, this nominal title was often associated with the establishment of the Crown Prince (Donggong wangfu 東宮王府). Conceivably, another reason for providing calligraphers with official titles may have arisen out of a desire for visual symmetry in the carved inscriptions of public monuments. The texts of stone steles and epitaphs required collaboration, and so the names and titles of the

4 See Charles Hucker, A Dictionary of Official Titles in Imperial China (Stanford: Stanford University Press, 1998, first published 1985), 5420 and 2803, for shuzhi 書直 (Auxiliary Scribe) and huazhi 畫直 (Auxiliary Illustrator). From 731 CE to the end of Tang dynasty, both were retitled zhiyuan 直院 (Auxiliary). For more on huazhi, see Li Wankang 李万康, “Tang dai Hanlinyuan hua daizhao renyong zhidu kao shu” 唐代翰林院画待诏任用制度考述, Gugong bouwyuan yuankan 故宫博物院院刊 4 (2017): 46-57, see pages 49-50. Li Wankang argues through the case of celebrated painter Wu Daozi 吳道子 (ca. 689-after 755) that huazhi and Hanlin daizhao were separate systems with similar stipend rankings until around the 9th century of the middle-Tang period, when more systematic regulations instituted daizhao as a promotion for huazhi.

5 See Li Jiebing 李潔冰 and Li Zhenggeng 李正庚, “Lun Tang dai shishu ji qi zhidu hua” 論唐代 侍書及其制度化, Xueshu jiaoliu 學術交流 4 (2008): 171-74. Wang Yuanjun 王元军, “Wan Tang yu nei gongfeng caoshu seng Bianguang shiji tantao” 晚唐御内供奉草书僧辩光事迹探讨, Zhongguo shufa 中国书法 2 (2005): 28-30, discusses titles held by Tang-dynasty monks in relation to known titles and combinations held by other calligraphers at court, including Hanlin gongfeng 翰林供奉, Hanlin daizhao 翰林待詔, shishu 侍書, shishu daizhao 侍書待詔, shishu xueshi 侍書學士, etc. 
officer who authored the text and the calligrapher who provided the handwriting may appear acknowledged together.

For someone with creative talent during the Tang, the highest possible achievement was to become Hanlin daizhao as a member of the Hanlin Academy, an institution that comprised of all the emperor's most valued courtiers - including scholars, poets, Buddhist and Daoist priests, alchemists, diviners, calligraphers, chess players, and artisans. Or as one Tang-period source put it, "all those under Heaven called to serve for their artistic and artisanal skills” 天下以藝能伎 術見召者. ${ }^{6}$ Another important post was nei gongfeng 内供奉. ${ }^{7}$ Under Emperor Tang Xuanzong 唐玄宗 (r. 712-56) in the 8th century, the title sometimes appears within a phrase referring to someone who is "called to serve in the inner palace" (zhao runei gongfeng 召入内供奉) or as a suffix to an official title. In either case, the title or suffix referred to people chosen on a rotational basis to be the emperor's close attendants, and the men on duty included those providing artistic services. ${ }^{8}$

By the mid-8th century, gongfeng became more distinct as a title and distinguishable from daizhao. Both titles were affiliated to the Hanlin Academy. This is known through the case of Liu Qin 劉秦 (8th century), a court calligrapher

6 Wei Zhiyi 韋執誼 (769-814), Hanlinyuan gushi 翰林院故事 (Stories of the Hanlin Institute), 786 CE, in Hong Zun 洪遵 (1120-74), comp. Hanyuan qunshu 翰苑群書 (Collected writings on the Hanlin Institute) (hereafter HYQS), 12 juan (Beijing: Zhonghua shuju, 1991), 11-16, see page 11. Also see Hong Zun, comp. Hanyuan yishi 翰苑遺事 (Incidents of past ages at the Hanlin Institute), in HYQS, 76-89, cited page 83. For surviving texts on the history of the Hanlin Academy and Hanlin Institute, see Friedrich Alexander Bischoff, La forêt des pinceaux: Étude sur l'Académie du Han-lin sous la dynastie des T'ang et traduction du Han lin tche, Bibliothèque de l'Institut des hautes études chinoises 17 (Paris: Presses Universitaires de France, 1963).

7 For an introduction to Hanlin daizhao and gongfeng titles held by Tang-dynasty calligraphers (monks included), see Wang Yuanjun 王元军, “Tang dai de Hanlin shu daizhao ji qi huodong kao shu” 唐代的翰林书待诏及其活动考述, Meishu yanjiu 美术研究 3 (2003): 100-104. Wang Yuanjun refutes other scholarship claiming Hanlin daizhao and Hanlin gongfeng to be synonymous. Also see Wang Haibin 王海宾, Tang dai Hanlin shu daizhao zhidu zongkao 唐代 翰林书待诏制度综考 (M.A. Thesis, Jilin University, 2008), for epitaphs and surviving steles related to this subject in addition to the transmitted texts.

8 See Hucker, Dictionary of Official Titles, 3418-3423, for variations on gongfeng (literally, "those who wait upon" or "those who serve"). From the Tang, gongfeng and nei gongfeng appear as a suffix or appendix to titles, referring to men chosen on rotational basis to be the emperor's close attendants and to qualified officials on duty within the palace awaiting regular appointment. Hucker, Dictionary of Official Titles, 3422, from Song onwards, Palace Attendant (gongfeng neiting 供奉內庭) is "a collective reference to various kinds of eunuchs, palace women, officials, and specially talented outsiders in painting, etc.” According to Gong Yanming, Songdai guanzhi, 598 and 591, Palace Servitor (gongfeng guan 供奉官) is established in $1112 \mathrm{CE}$ as the highest of twelve rank titles granted to eunuchs. 
whose title sequences are detailed in two surviving epitaphs where he is recorded as the calligrapher. ${ }^{9}$ Liu served as Hanlin Academy gongfeng under Emperor Tang Xuanzong in 754 CE. He was promoted seven years later in 761 CE to Hanlin Academy daizhao under the next emperor, Tang Suzong 唐肃宗 (r. 756-62). His title sequences, before and after promotion, begin with a ranked prestige title followed by another ranked title for salary grade through an affiliation to a palace agency. Both sequences end with his function as calligrapher, with an unranked title indicating his level within the Hanlin Academy's hierarchy. Thus, we can examine the dynamics between Liu's personal rank and salary grade versus his actual job as calligrapher during this moment of career transition.

Before promotion, $754 \mathrm{CE}$ :

Gentleman for Court Discussion (Rank 6a1),

Acting (xing) Director of Gatekeepers (Rank 6b2) in the Heir Apparent's Household, and Hanlin Academy gongfeng. ${ }^{10}$

朝議郎, 行太子宮門郎, 翰林院供奉

After promotion, $761 \mathrm{CE}$ :

Gentleman for Court Discussion (Rank 6a1),

Acting (xing) Aide at the Court of Imperial Regalia (Rank 6b1),

and Hanlin Academy daizhao. ${ }^{11}$

朝議郎, 行衛尉寺承, 翰林院待詔

\footnotetext{
9 For Liu Qin’s 劉秦 (8th century) epitaph dated 754 CE (Tianbao 天寶 13) that records his service as a calligrapher, see Zhou Shaoliang 周紹良 and Zhao Chaofu 趙超副 eds., Tangdai muzhi huibian 唐代墓誌彙編 (Compilation of Tang dynasty epitaphs), 2 vols. (Shanghai: Shanghai guji chubanshe, 1992), see vol. 2, 1711-12: Tianbao 258, "Da Tang Huang gu di wu sun muzhiming” 大唐皇故第五孫墓誌銘. For his epitaph dated $761 \mathrm{CE}$ (Shangyuan 上元 2), see Lu Zengxiang 陆增祥, Baqiong shi jinshi buzheng 八琼室金石补正, juan 59 (Beijing: Wenwu chubanshe, 1985), 407: “Liu Fengzhi muzhi” 劉奉芝墓誌.

10 For Gentleman for Court Discussion (Chaoyi lang 朝議郎), see Tang liu dian 唐六典, j. 2; Hucker, Dictionary of Official Titles, 325. For Director of Gatekeepers in the Heir Apparent's Household (Taizi gongmen lang 太子宮門郎), see Tang liu dian, j. 26; Hucker, Dictionary of Official Titles, 3451. Two Directors were responsible for gatekeeping duty in the Heir Apparent's household.

11 For Aide at the Court of Imperial Regalia (Weiwei si cheng 衛尉寺承), see Tang liu dian, j. 16. Hucker, Dictionary of Official Titles, 7683: the Court of Imperial Regalia was in charge of "manufacturing and storing weapons, tents, insignia, and other kinds of military regalia." See also Gong Yanming, Songdai guanzhi, 304: a salary rank (Rank 6b1) from Tang to early Song. Also Gong, 688, Table 12, \#27: a salary rank in the Song dynasty that converted to Rank 8b2 during the Yuanfeng era 元豐 (1078-1085).
} 
This is a good example of how the bureaucracy's dual-ranking system was applied in the case of an artist. Note that Liu kept the same prestige title as Gentleman for Court Discussion while changing his salary grade from Director of Gatekeepers in 754 CE to Aide at the Court of Imperial Regalia in 761 CE. However, even as Liu's salary was increased from Rank $6 \mathrm{~b} 2$ to Rank 6b1, the prefix xing 行, “acting," is used to differentiate him from regular officers and to indicate that he was actually of lower status than was appropriate for the office (or that the office was temporary). Besides a pay increase, we further surmise a change in Liu's status per others at the Hanlin Academy because he was appointed gongfeng and daizhao in succession. Now holding the Hanlin Academy's top post, his standing was augmented even without a concurrent increase in his personal rank as Gentleman for Court Discussion.

The artist title Hanlin daizhao survives the fall of Tang, and aspects of both Tang and 10th-century legacies for rewarding painters survive Song unification. In the below, we examine how the 8th-century Tang practice of titling calligraphers Hanlin daizhao together with a sequence of seniority or stipendiary titles was extended to top painters more consistently by the 10th century in Sichuan. For painters' titles, the most distinctive pattern that I found relates to Hanlin daizhao plus honors ( $c i$ 賜, henceforth $c i$-honors) as the base qualification to be considered for extra income and lofty recognition through a prestige title and, above that, an additional sinecurial merit title (xun 勳). Another interesting pattern is the use of modifying prefixes such as “acting1” (jianjiao 檢校), “acting2" (shou 守), and “probationary” (shi 試), denoting painters’ offices as temporary, rotational, or honorary. In Sichuan, such titles may indicate (temporary?) salary increases or perhaps they were extravagant ornaments to one's name. Yet the ornamentation was purposeful: high titles for painters not only raised the status of individual talents but also the overall prestige of Sichuan's painting traditions.

\section{A spatial methodology}

An imperial city's economy of power is expressed through an amalgam of physical and non-physical relationships, such as in locating government office buildings near the emperor and accommodating the bureaucracy of officers within palace walls and institutions. Take for example the expressions inner court (neiting 內庭) and outer court (waichao 外朝) describing those who served in the Song dynasty's imperial city. The former comprised the emperor's extended household, including empresses, eunuchs, and top artists, whereas the 
latter were civil-service officials entrusted with the power to discharge governance or to administer the central government's communications and records, from high ministers to library staff. Of course, each class of people had their own distinct, ranked hierarchies, but within the imperial city, the inner and outer courts combined their capacities.

For instance, the Institute of the Assembled Wise (Jixiandian 集賢殿) and the Hanlin Institute of Academicians (Hanlin xueshiyuan 翰林學士院) were populated by scholar-officials of the outer court but as non-administrative, advisory bodies, paralleled the inner court for their informal access to the emperor. Both Institutes were allowed to use calligraphers and painters attending the emperor in his palaces as their support staff. These elite artists-in-waiting generally held the top title of Hanlin daizhao as part of the inner court's Hanlin Academy, a eunuch-supervised organ. As expected, painters from the Tang to the Song dynasty were mainly members of the inner court but, surprisingly, they sometimes simultaneously held stipendiary outer-court titles. Great differences in social status between inner and outer court members notwithstanding, artists occasionally borrowed their bureaucratic location from the organizations which they served. Our attention to whether artist titles stem from the inner or outer court is therefore a study of spatial operations, but this analysis also has historical and geographic dimensions.

Inherently a spatial construct, titular rank in the official bureaucracy articulates one's hierarchic location relative to other officers. Expressed as inner or outer, civil or military, left or right, regular or honorary, permanent or temporary, an appointee's title sequence contains a precise calculation of rank and status negotiated in bureaucratic time and space. Sequences are combined from different categories to create different permutations, and they comprise of highly technical information to define a regular officer's personal rank and salary as opposed to his job. The prestige title noted above is one such category and the merit title is another. In the Tang dynasty, prestige titles were awarded based on nobility, meritorious service, performance assessment, morality, etc. They determined seniority for salary and allowances and (except for in the early Song dynasty) had no relation to an officer's actual function. Prestige titles are divided into two hierarchies. During the Tang, members of the civil service had twenty-nine levels from Rank 1b to 9b2, whereas the military service had forty-five levels for men with administrative responsibilities rather than those engaged in active military action (henceforth civil prestige title and military prestige title). Merit titles were originally non-hereditary awards for military achievement in the Tang, honorifics for 
both civil and military officers that were automatically earned along with personal rank and did not exceed it. ${ }^{12}$

Civil prestige titles were extended to elite artists and eventually merit titles too - first to calligraphers then painters. Artists were rarely given these kinds of titles and reports of the occasions usually survive only in fragments. Indeed, studying arcane nomenclature with such a small data set entails many complications, but some of the difficulties can be overcome by applying a spatial methodology. In fact, there are multiple ways to apply a spatial frame to artist titles and institutions and the results generated from different approaches have rich and related implications.

Since the Hanlin Academy took various forms as it evolved in different geographic regions during the 10th century, I noted versions of the institution for its political symbolism in a previous study. There were some similarities and variations in the Hanlin Academy organized by powers in different places: the Southern Tang court in Nanjing; the Former and Later Shu courts in Sichuan; and the Academy at the Song capital in Bianliang under the first Song dynasty emperors. As these powers each purported to revive a venerable Tang institution, thus the data takes on geospatial form. ${ }^{13}$

On the topic of artist titles, I have focused more specifically on the shape of the Song dynasty's Hanlin Painting Academy. This ongoing project takes hierarchy itself as the subject of analysis. The Song clearly built its Academy with more official tiers than ever before, but it is important to be aware of the many reasons for deepening hierarchy. One enduring factor was the technocratic need to classify artistic ability - to grade painters according to their skills and to define technical standards of painting practice. My research also elucidates how a taller hierarchy with more levels provided the means to combine painters recruited from different channels, such as by invitation, recommendation, and competition. During the founding of the Song dynasty, it was useful for integrating those

12 These definitions are based on Hucker, Dictionary of Official Titles, 4868 and 2711, and Xie Baocheng, trans. Chen Mirong, A Brief History of the Official System in China (London: Paths International Ltd., and Social Sciences Academic Press, China, 2013), "Ranks, titles, and salaries," 173-85. For further discussion of the changes enacted for prestige titles in the Song period, see Gong Yanming, Songdai guanzhi, 30-32. As did painters on occasion, the palace eunuch corps shared civil-service officer titles before they had their own scale of twelve levels by $1112 \mathrm{CE}$.

13 See Foong Ping, "The Structural Position of Court Artists in the Song Dynasty: Issues of Rank, Title and Legitimate Rule During the Founding Decades” 宋代宮廷畫家的官署機構, in Wu Hung, ed., Tenth-Century China and Beyond: Art and Visual Culture in a Multi-centered Age (Chicago: Center for the Art of East Asia, University of Chicago, and Art Media Resources, 2013), 350-63. 
repatriated or captured from enemy territory, since artists too had to be suitably assimilated under Song rule. ${ }^{14}$

The present paper aims to further develop a spatial methodology for interpreting artist titles. Mentioned in the above survey of Tang nomenclature, upper-echelon artists mostly derived status from their positions as inner-court servitors. However, some rose above their technocratic function with the personal ranks and associated emoluments of outer-court officials. As for regular officers, it is important to distinguish rank and status from function for artists. But studying top artists also requires our close attention to two properties that underlie their title sequences, namely, hierarchy and classification. Hierarchy indicates somebody's relative standing higher or lower in a scale. Classification conceives of the appointee's status or function in relation to the inner court or outer court.

The case of Tang calligrapher Liu Qin discussed above well illustrates the need to examine each component of his title sequence for these two spatial properties. Recall now that Liu's title sequence establishes his structural location in three ways: through a personal title and rank; a salary title and rank; and a functional title. His civil prestige title establishes his place in a scale shared with outer-court civil officers. His salary originates from inner-court palace agencies, namely, the establishment of the Crown Prince before promotion, and Court Regalia after promotion. His artist title indicates his level at the Hanlin Academy as a member of the inner court. Unlike an officer's substantive, ranked duty assignment indicating work, titles at the academy are unranked. Instead, they judge the holder's skill level as an artist. At first graded Hanlin gongfeng, Liu Qin was re-evaluated worthy of rising to Hanlin daizhao and thus promoted.

We must note that the classification of Liu Qin's inner-court or outer-court status is neither static nor easily fixed. Indeed, complications in classification arise from the social standing and education of the appointee and from temporality, whether a position is ad hoc or permanent. Do we classify a calligrapher's zhi 直 duty at the Academy of Scholarly Worthies as outer court since it was a scholar's institution? How do we describe artists who served as supporting staff to central government officers as opposed to civil-service officers who

14 The evidence for how the Song Hanlin Painting Academy was impacted by its adoption of the Shu kingdom's system of painters' titles is discussed in Foong Ping, "Representing Nation at the Painting Academy of Song Taizong," on the panel, "Song Taizong's Culture Revolution: The Transformation of Imperial Art, Literature, and Statecraft during the Late Tenth Century," Asia in Motion: Ideas, Institutions, Identities. AAS-in-ASIA, Academia Sinica, Taipei, Taiwan, 2015. 
also served as artists - are they inner or outer? Despite these hurdles it nevertheless remains important to evaluate how a title describes the value of an artist's service: whether closer to statecraft and hence to the outer court, or further away from statecraft and hence closer to the imperial court. An artist's standing is clearly not describable in black and white terms and indeed we discover the careers of calligraphers and painters expressed with ranks along an inner-outer continuum through a variety of accommodations in middle-period China.

In the below, we engage with the topic of Sichuan's painters as an innerouter court spatial problem. For 9th- and 10th-century painters in the Shu kingdom, syntactical patterns come to light amidst bewildering detail from arranging their titles according to titular categories analogous to those discovered in Liu Qin's 8th-century case. Greater resolution is indeed gained by differentiating titles that denote artistic function and ability from those assumed from the outer court - that is, by paying attention to both hierarchy and classification.

\section{Sichuan's painters according to Huang Xiufu}

The most important source for middle-period painters' titles is undoubtedly Huang Xiufu's 黃休復 (b. ca. 954-59) Yizhou minghua lu 益州名畫錄 (Record of Famous Paintings in Yizhou). This book contains detailed descriptions of the careers of 10th-century Shu painters. Other early catalogs that modern scholars rely on for painters' biographies typically only include fragments of titular information, whereas Huang's contemporary account records full title sequences. Indeed, given his meticulous documentation, we can presume that the Sichuan native Huang Xiufu had access to original records not available to other authors. ${ }^{15}$

The table in Figure 1 contains all painters recorded in Huang Xiufu's book who received either Hanlin daizhao and/or official regalia from the late-9th to the 10th century. Eighteen distinct names are arranged roughly in chronological order. The list begins with late-Tang court painters Lü Yao, Zhu Qian, and

15 An important English-language study of Huang Xiufu's 黄休復 (b. ca. 954-59) Yizhou minghua $l u$ 益州名畫錄 (Record of Famous Paintings in Yizhou) is Evelyne Mesnil, "Didactic Paintings between Power and Devotion: The Monastery Dashengcisi 大聖慈寺 in Chengdu (8th-10th c.),” in Christian Wittern and Shi Lishan eds., Essays on East Asian Religion and Culture: Festschrift in honour of Nishiwaki Tsuneki on the occasion of his 65th birthday (Kyoto: Editorial committee for the Festschrift in honor of Nishiwaki Tsuneki, 2007), 98-148. Mesnil has published extensively in French on the arts of the Shu kingdom. 
Chang Zhongyin 常重胤 (9th century) who served Emperor Tang Xizong 唐僖宗 (r. 873-88). Lü and Zhu had already attained the level of Hanlin daizhao at the Tang court before arriving in Sichuan, whereas Chang received his title in Sichuan during Emperor Xizong's exile there. The author Huang Xiufu regarded the three men as Shu painters even though they were not Sichuan natives. The Sichuan natives recorded by Huang served as painters mostly under the Wang and Meng regimes of Shu. Note that Huang Quan and Huang Jucai each appear twice in the table. Huang Quan's second appearance near the end of the list refers to his final promotion in Shu, whereas the very last entry in the table records a set of titles that Huang Jucai received from the early Song-dynasty emperors after relocating from Sichuan to the Song capital of Bianliang.

Figure 1's titular categories are arranged in columns from left to right. Titles pertaining to the inner court are at left, outer court at right; unranked titles at left, ranked titles at right. The one exception is ci-honors. As earlier mentioned, official regalia comprising robes and the fish-pouch insignia visually displayed the ranks of regular officials, but high-ranked robe colors in purple and crimson were occasionally extended to calligraphers and painters. Title sequences invariable list ci-honors last, after someone's commission or merit title at the end of the sequence. And indeed this is the form for painters' titles in Huang Xiufu's book. But rather than follow this syntax, $c i$-honors is instead located adjacent to the Hanlin Academy column in our table because it sharpens the pattern. There is no detriment to the data's integrity in doing so because ci-honors are awarded to practically all the Hanlin daizhao listed and therefore can be treated as tied together reliably for our analysis.

By arranging Huang Xiufu's records according to their titular categories in Figure 1, we can now draw some initial conclusions. First, Sichuan's painters were rewarded the Hanlin daizhao title in much greater numbers than the Tang court. Not including Lü Yao, Zhu Qian, and Chang Zhongyin, who received their titles under Emperor Tang Xizong, fifteen awards were made over a period of about sixty years during the Former Shu 前蜀 (907-25) and Later Shu under the Wang and Meng regimes. Nearly all received ci-honors as well - either purple robes plus gold fish-pouch, or crimson robes plus fish-pouch. In other words, Hanlin daizhao was practically synonymous with robes of office in 10th-century Sichuan. Second, this level of achievement was, in turn, the base qualification for additional outer-court titles. We discover from Figure 1 that a subset of five men received this consideration with prestige titles and other honorifics: Ruan Zhihui 阮知誨 (10th century), his son Ruan Weide 阮惟德 (10th century), Huang Quan, his son Huang Jucai, and Li Wencai 李文才 (10th century). However, the honorifics or commissions of these five men were prefixed “acting1” (jianjiao), “acting2” (shou), or "probationary” (shi). Just as Tang 


\begin{tabular}{|c|c|c|c|c|c|c|c|c|c|c|c|c|c|c|}
\hline \multirow[t]{3}{*}{ Date } & \multirow[t]{3}{*}{ Served } & \multirow{3}{*}{\begin{tabular}{|l|} 
Name \\
$\begin{array}{l}f / o \text { Father of } \\
\text { s/o Son of }\end{array}$ \\
\end{tabular}} & \multicolumn{9}{|c|}{ Inner court title and function } & \multicolumn{3}{|c|}{ Outer court title and rank } \\
\hline & & & \begin{tabular}{|l|}
$\begin{array}{l}\text { Palace } \\
\text { title }\end{array}$ \\
\end{tabular} & \begin{tabular}{|l|} 
Hanlin \\
Academy
\end{tabular} & Ci-honors 唄 & \begin{tabular}{|l|}
$\begin{array}{l}\text { Other } \\
\text { function }\end{array}$ \\
\end{tabular} & Prestige title 散官 & \begin{tabular}{|l} 
Rank \\
品級
\end{tabular} & 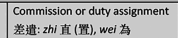 & \begin{tabular}{|l} 
Rank \\
品級
\end{tabular} & \begin{tabular}{|l} 
Merit title \\
整陵
\end{tabular} & \begin{tabular}{|l|} 
Rank \\
品制
\end{tabular} & \begin{tabular}{|l|}
$\begin{array}{l}\text { Salary rank } \\
\text { 寄淥官 }\end{array}$ \\
\end{tabular} & \begin{tabular}{|l} 
Rank \\
品级
\end{tabular} \\
\hline & & & & & & & $\begin{array}{l}\text { (C) Civil prestige title } \\
\text { 文散官 } \\
\text { (M) Military prestige } \\
\text { title } \\
\text { 武散官 }\end{array}$ & & 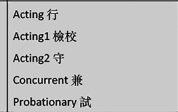 & & & & & \\
\hline $\begin{array}{l}880- \\
885\end{array}$ & \begin{tabular}{|l} 
Tang Xizong \\
in Shu \\
鹿僖宗
\end{tabular} & Lū Yao 呂责 & & \begin{tabular}{|l} 
(Previously) \\
Hanlin daizhao \\
翰林待初
\end{tabular} & $\begin{array}{l}\text { Crimson robes, } \\
\text { Fish-pouch } \\
\text { 䠊魚袋 }\end{array}$ & & \begin{tabular}{|l} 
(C) Court Gentleman for \\
Ceremonial Service \\
將仕郎
\end{tabular} & $9 \mathrm{~b} 2$ & 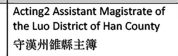 & $\begin{array}{l}9 \mathrm{ga2}- \\
9 \mathrm{~b} 1\end{array}$ & & & & \\
\hline $\begin{array}{l}880- \\
885\end{array}$ & $\begin{array}{l}\text { Tang Xizong } \\
\text { in Shu }\end{array}$ & Zhu Qian 竹度 & & \begin{tabular}{|l} 
(Previously) \\
Hanlin daizhao \\
翰林待袺
\end{tabular} & $\begin{array}{l}\text { Crimson robes, } \\
\text { fish-pouch } \\
\text { 绯魚袋 }\end{array}$ & & $\begin{array}{l}\text { (C) Court Gentleman for } \\
\text { Ceremonial Service } \\
\text { 將仕郎 }\end{array}$ & $9 \mathrm{b2}$ & $\begin{array}{l}\text { Acting2 Assistant Magistrate of } \\
\text { the Luo District of Han County } \\
\text { 守漢州䬺傆主簿 }\end{array}$ & $\begin{array}{l}9 \mathrm{ga2}- \\
9 \mathrm{~b} 1\end{array}$ & & & & \\
\hline 885 & $\begin{array}{l}\text { Tang Xizong } \\
\text { in Shu }\end{array}$ & $\begin{array}{l}\text { Chang Zhongvin 常重/海 } \\
\text { s/o Chang Can 营策 }\end{array}$ & & \begin{tabular}{|l} 
Hanlin daizhao \\
翰林待沼
\end{tabular} & $\begin{array}{l}\text { Crimson robes, } \\
\text { fish-pouch } \\
\text { 緋魚袋 }\end{array}$ & & & & & & & & & \\
\hline $907-$ & \begin{tabular}{|l} 
Wang \\
regime
\end{tabular} & $\begin{array}{l}\text { Zhao Deqi 趙德齊 } \\
\text { s/o Zhao Wenq 速溫奇 }\end{array}$ & & $\begin{array}{l}\text { Hanlin daizhao } \\
\text { 朝林待詔 }\end{array}$ & $\begin{array}{l}\text { Purple robes, } \\
\text { gold fish-pouch } \\
\text { 紫金魚裁 }\end{array}$ & & & & & & & & & \\
\hline 907- & \begin{tabular}{|l|} 
Wang \\
regime
\end{tabular} & $\begin{array}{l}\text { Gao Daoxing 高道與 } \\
\text { f/o Gao Congyu 高從遇 } \\
\text { and Gao Wenjin 高文進 }\end{array}$ & & 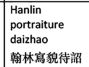 & $\begin{array}{l}\text { Purple robes, } \\
\text { gold fish-pouch } \\
\text { 齿金魚袋 }\end{array}$ & & & & & & & & & \\
\hline 907. & $\begin{array}{l}\text { Wang Jian } \\
\text { 王建 }\end{array}$ & $\begin{array}{l}\text { Fang Chongzhen } \\
\text { 序垼真 }\end{array}$ & & $\begin{array}{l}\text { Hanlin daizhao } \\
\text { 翰林待沼 }\end{array}$ & $\begin{array}{l}\text { Purple robes, } \\
\text { gold fish-pouch } \\
\text { 齿金魚袋 }\end{array}$ & & & & & & & & & \\
\hline 907- & Wang Jian & Song Yi宋萑 & & \begin{tabular}{|l|} 
Hanlin daizhao \\
朝林待噭
\end{tabular} & & & & & & & & & & \\
\hline 918- & $\begin{array}{l}\text { Wang Yan } \\
\text { 王街 }\end{array}$ & Du Nigui 杫解鬼 & & \begin{tabular}{|l|} 
Hanlin daizhao \\
翰林待沼
\end{tabular} & $\begin{array}{l}\text { Purple robes, } \\
\text { gold fish-pouch } \\
\text { 紫金魚惐 }\end{array}$ & & & & & & & & & \\
\hline 919- & $\begin{array}{l}\text { Wang Yan } \\
\text { and Meng } \\
\text { Zhixiang } \\
\text { 孟知样 }\end{array}$ & \begin{tabular}{|l|l|} 
Ruan Zhihui 㐾知請 \\
\end{tabular} & & 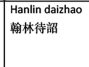 & & & $\begin{array}{l}\text { (C) Grand Master of } \\
\text { Imperial Entertainments } \\
\text { with Silver Seal and Blue } \\
\text { Ribbon 银青光榢大夫 }\end{array}$ & $3 b$ & 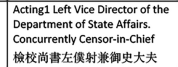 & $3 \mathrm{~b}$ & \begin{tabular}{|l} 
Supreme \\
Pillar of \\
State \\
上柱國
\end{tabular} & $2 a$ & & \\
\hline 925 - & \begin{tabular}{|l|} 
Meng \\
Zhixiang
\end{tabular} & Zhang Mei 张玫 & & \begin{tabular}{|l} 
Hanlin daizhao \\
朝林待沼
\end{tabular} & $\begin{array}{l}\text { Purple robes, } \\
\text { gold fish-pouch } \\
\text { 紫金魚裁 }\end{array}$ & & & & & & & & & \\
\hline 925- & \begin{tabular}{|l|} 
Meng \\
Zhixiang
\end{tabular} & Huang Quan 黄鉒 & & \begin{tabular}{|l} 
Hanlin daizhao \\
翰林待磂
\end{tabular} & $\begin{array}{l}\text { Purple robes, } \\
\text { gold fish-pouch } \\
\text { 紫金魚襲 }\end{array}$ & \begin{tabular}{|l} 
Overseer \\
of \\
Academy \\
affairs \\
權院事 \\
\end{tabular} & & & & & & & & \\
\hline 925- & \begin{tabular}{|l|} 
Meng \\
regime
\end{tabular} & $\begin{array}{l}\text { Huang Jubao 黄居實 } \\
\text { 2nd s/o Huang Quan }\end{array}$ & & \begin{tabular}{|l} 
Hanlin daizhao \\
翰林待沼
\end{tabular} & $\begin{array}{l}\text { Purple robes, } \\
\text { gold fish-pouch } \\
\text { 紫金魚袚 }\end{array}$ & & & & & & & & & \\
\hline 925- & \begin{tabular}{|l|} 
Meng \\
regime
\end{tabular} & Pu Shixun 浦師剖 & & $\begin{array}{l}\text { Hanlin daizhao } \\
\text { 翰林待沼 }\end{array}$ & \begin{tabular}{|l} 
Purple robes, \\
gold fish-pouch \\
紫金魚袋
\end{tabular} & & & & & & & & & \\
\hline 925- & \begin{tabular}{|l|} 
Meng \\
regime
\end{tabular} & $\begin{array}{l}\text { Ruan Weide 阮推德 } \\
\text { s/o Ruan Zhihui 阮知㵵 }\end{array}$ & & \begin{tabular}{|l} 
Hanlin daizhao \\
朝林待浔
\end{tabular} & $\begin{array}{l}\text { Crimson robes, } \\
\text { fish-pouch } \\
\text { 䠊魚袋 }\end{array}$ & & $\begin{array}{l}\text { (C) Court Gentleman for } \\
\text { Ceremonial Service } \\
\text { 將仕郎 }\end{array}$ & $9 \mathrm{b2}$ & $\begin{array}{l}\text { Probationary Court Gentleman } \\
\text { for Fasting in the Court of } \\
\text { Imperial Sacrifices } \\
\text { 試太常寺第郎 }\end{array}$ & $n / a$ & & & & \\
\hline 925- & \begin{tabular}{|l|} 
Meng \\
regime
\end{tabular} & $\begin{array}{l}\text { Huang Jucai 黄居案 } \\
\text { 5th s/o Huang Quan }\end{array}$ & & $\begin{array}{l}\text { Hanlin daizhao } \\
\text { 翰林待沽 }\end{array}$ & $\begin{array}{l}\text { Purple robes, } \\
\text { gold fish-pouch } \\
\text { 紫金魚惐 }\end{array}$ & & $\begin{array}{l}\text { (C) Court Gentleman for } \\
\text { Ceremonial Service } \\
\text { 將仕郎 }\end{array}$ & $9 \mathrm{~b} 2$ & $\begin{array}{l}\text { Probationary Court Gentleman } \\
\text { for Consultation for the Heir } \\
\text { Apparent } \\
\text { 試太子蓄郎 }\end{array}$ & $n / a$ & & & & \\
\hline 934- & \begin{tabular}{|l}
$\begin{array}{l}\text { Meng Chang } \\
\text { 盃神 }\end{array}$ \\
\end{tabular} & Li Wencai 李文才 & & \begin{tabular}{|l|} 
Hanlin daizhao \\
献林待涩
\end{tabular} & $\begin{array}{l}\text { Crimson robes, } \\
\text { fish-pouch } \\
\text { 緋魚㲤 }\end{array}$ & & $\begin{array}{l}\text { (C) Court Gentleman for } \\
\text { Ceremonial Service } \\
\text { 將仕郎 }\end{array}$ & $9 \mathrm{~b} 2$ & $\begin{array}{l}\text { Probationary Remonstrance } \\
\text { Secretary for the Heir Apparent } \\
\text { 試太子 [数坊] 司諘郎 }\end{array}$ & $6 a$ & & & & \\
\hline 934- & Meng Chang & \begin{tabular}{|l} 
Du Jingan 杜做安 \\
s/o Du Zixiang 杜子瓖
\end{tabular} & & \begin{tabular}{|l|} 
Hanlin daizhao \\
朝林待韶
\end{tabular} & $\begin{array}{l}\text { [Purple] robes, } \\
\text { gold fish-pouch } \\
\text { [橸]金魚袋 }\end{array}$ & & & & & & & & & \\
\hline 934- & Meng Chang & $\begin{array}{l}\text { Zhao Zhongyi 趙忠義 } \\
\text { s/o Zhao Dexuan } \\
\text { 趋德玄 }\end{array}$ & & \begin{tabular}{|l} 
Hanlin daizhao \\
朝林待初
\end{tabular} & $\begin{array}{l}\text { Purple robes, } \\
\text { gold fish-pouch } \\
\text { 紫金魚袋 }\end{array}$ & & & & & & & & & \\
\hline $\begin{array}{l}938- \\
965\end{array}$ & Meng Chang & \begin{tabular}{l|} 
Pu Yanchang 㜑延吕 \\
s/o Pu Shixun 㜑皈部
\end{tabular} & & & $\begin{array}{l}\text { Crimson robes, } \\
\text { fish-pouch } \\
\text { 緋魚袋 }\end{array}$ & & & & & & & & & \\
\hline $\begin{array}{l}\text { After } \\
944\end{array}$ & Meng Chang & Huang Quan & $\begin{array}{l}\text { Nei } \\
\text { gongfeng } \\
\text { 內供奉 }\end{array}$ & $\begin{array}{l}\text { Hanlin daizhao } \\
\text { 翰林待詔 }\end{array}$ & & & $\begin{array}{l}\text { (C) Grand Master for } \\
\text { Court Discussion } \\
\text { 胡議大夫 }\end{array}$ & $5 \mathrm{a} 2$ & $\begin{array}{l}\text { Acting1 Vice Director of the } \\
\text { Directorate for Imperial } \\
\text { Manufactories } \\
\text { 检校少府少監 }\end{array}$ & $4 \mathrm{~b} 2$ & $\begin{array}{l}\text { Supreme } \\
\text { Pillar of } \\
\text { State } \\
\text { 上柱國 }\end{array}$ & $2 \mathrm{a}$ & & \\
\hline $\begin{array}{l}\text { After } \\
965\end{array}$ & $\begin{array}{l}\text { Song Taizu, } \\
\text { Taizong } \\
\text { 本太祖 } \\
\text { 末太宗 }\end{array}$ & Huang Jucai & & \begin{tabular}{|l|}
$\begin{array}{l}\text { Hanlin daizhao } \\
\text { 朝林待沼 }\end{array}$ \\
\end{tabular} & $\begin{array}{l}\text { Purple robes, } \\
\text { gold fish-pouch } \\
\text { 紧金魚袋 }\end{array}$ & & $\begin{array}{l}\text { (C) Grand Master for } \\
\text { Court Audiences } \\
\text { 胡請大夫 }\end{array}$ & $5 \mathrm{~b} 1$ & & & \begin{tabular}{|l} 
Supreme \\
Pillar of \\
State \\
上柱國
\end{tabular} & $2 a$ & \begin{tabular}{|l}
$\begin{array}{l}\text { Aide of the } \\
\text { Courts (?) } \\
\text { 寺丞 }\end{array}$ \\
\end{tabular} & $?$ \\
\hline
\end{tabular}

Figure 1: Painters' titles in Yizhou minghua lu 益州名畫錄 (Record of Famous Paintings in Yizhou) by Huang Xiufu 黄休復 (b. ca. 954-59). 
calligrapher Liu Qin's salary rank was modified by “acting” (xing), these other qualifiers defined the outer-court ranks held by the five top Shu painters as nominal, honorary, or temporary.

From Figure 1, we see that Ruan Zhihui and Huang Quan held the very highest ranks in 10th-century Shu. On top of their prestige title, they were additionally granted the highest available merit title of Supreme Pillar of State (Shangzhuguo 上柱國) (Rank 2a). According to Tang rules, a merit title conveys the privilege of official robes in a certain color and Supreme Pillar of State theoretically entitles an awardee the right to annex thirty qing of land by equitablefield (juntian 均田) land-ownership principles. We cannot assume that Tang principles were followed in Sichuan, but it is nevertheless interesting to see Supreme Pillar of State used to raise Ruan and Huang above their peers. ${ }^{16}$

Ruan Zhihui served as Hanlin daizhao under the reigns of Former Shu's second ruler, Wang Yan 王衍 (901-26, r. 918-25), and founder of Later Shu, Meng Zhixiang. He was the most prominent of all Shu painters, and if his titles are any measure, the penultimate painter of 10th-century Sichuan. This is because Ruan was simultaneously recognized with titles in three ranked, outer-court categories: a civil prestige title, commission, and merit title:

\section{Grand Master of Imperial Entertainments with Silver Seal and Blue Ribbon (Rank 3b), Acting1 (jianjiao) Left Vice Director of the Department of State Affairs and concurrently Censor-in-Chief (Rank 3b), Supreme Pillar of State (Rank 2a). \\ 銀青光祿大夫, 檢校尚書左僕射, 兼御史大夫上柱國}

As we might expect, Ruan Zhihui's lofty title as "Left Vice Director of the Department of State Affairs and concurrently Censor-in-Chief” is modified by "acting1” 檢校 to indicate that his commission was not substantive. That is, Ruan probably didn't serve in capacities stated in the title but nevertheless was allowed to enjoy the high rank's prestige.

Serving about twenty-five years after Ruan Zhihui under Meng Chang, second ruler of Later Shu, Huang Quan held titles in the same three outer-court categories. However, Huang's civil prestige title as Grand Master for Court Discussion 朝議大 夫 (Rank 5a2) was lower than Ruan's Grand Master of Imperial Entertainments

16 Supreme Pillar of State (Shangzhuguo 上柱國) was the highest of twelve merit title ranks in the Tang dynasty. Modern scholars Chen Zhongfu 陈仲夫 and Wang Su 王素 point out that even though the title is recorded in Dunhuang and Turfan manuscripts, not a single person received actual land rights. See Chen Zhongfu 陈仲夫 and Wang Su 王素 eds., Han-Tang zhiguan zhidu yanjiu 汉唐职官制度研究 (Study of the official system in Han and Tang dynasties) (Beijing: Zhonghua shuju, 1993), 98. 
with Silver Seal and Blue Ribbon (Rank 3b). Huang's commission as Acting1 Vice Director of the Directorate for Imperial Manufactories 檢校少府少監 (Rank 4b2) was also below Ruan (Rank 3b). ${ }^{17}$ Thus, we surmise that Huang's rank was below Ruan even though both discharged their painterly duties as Hanlin daizhao. Regardless, their outer-court titles may have enabled Ruan and Huang to join court audiences according to established protocol for regular officers of the outer court.

In summary, outer court means of recognition - appropriately discounted were permitted to a few painters under the Wang and Meng regimes. These high designations may or may not have represented actual stipends or other emoluments. It is also unknown to what extent they rewarded artistic skill rather than administrative ability, or some combination. In any case, they undoubtedly demonstrate that Shu rulers held Sichuan's top artists in the highest esteem, and that Wang Yan, Meng Zhixiang, and Meng Chang found bureaucratic means to extend recognition to certain painters. However, these rulers' unusual use of the commission and merit title categories requires further scrutiny. In the following sections we consider the cases of Tang painters Lü Yao, Zhu Qian, and Cheng Xiuji, whose titles may have provided a model.

\section{The precedent of Lü Yao and Zhu Qian}

The titular sequences of Ruan Zhihui and Huang Quan appear to follow in the footsteps of Tang-dynasty painters Lü Yao and Zhu Qian, who received a prestige title plus a commission while in Sichuan during the late 9th century. Similarities between Lü and Zhu's title categories and those of Ruan and Huang suggest in the latter an effort to transmit canonical Tang titles in Sichuan. The only apparent difference is that the ranks offered to the two Sichuan painters were significantly more generous. However, even though we can identify continuities between painters' titles of the 9th and the 10th centuries, further analysis of Sichuan's application of Tang practice brings light to aspects that the Shu rulers innovated.

Keeping in mind Sichuan's system as exemplified by Ruan Zhihui and Huang Quan, let us consider the special situation that warranted Lü Yao and Zhu Qian's title sequence. From the little that survives in standard biographical

17 Huang Quan received Hanlin daizhao with purple robes plus gold fish-pouch ci-honors under Meng Zhixiang after 925 CE. Then he was (additionally?) titled nei gongfeng under Meng Chang after 944 CE. This evidence complicates our above analysis of Tang calligrapher Liu Qin proposing Hanlin daizhao as a promotion from nei gongfeng. 
sources, we know Lü served as Hanlin daizhao between 873 and 888 CE. He was one of only three or four painters awarded this prestigious title at the Tangdynasty capital of Chang'an. Lü left important Buddhist figural paintings at both Chang'an and Chengdu, the Shu capital, because he joined Emperor Tang Xizong's entourage during the emperor's exile in Sichuan from 880 to 885 CE. In other words, Lü was appointed Hanlin daizhao in Chang'an and kept this title after returning to Chang'an following the Tang emperor's Sichuan period.

Promotions offered to men with identical career tracks are often listed together in written sources, and Huang Xiufu lists Zhu Qian together with Lü Yao's name. Since Zhu also traveled to Sichuan with Emperor Tang Xizong, it seems likely that he received the same stipendiary titles as Lü even though Huang does not explicitly record them. Figure 1 therefore lists Zhu's name with Lü's titles. Zhu's identity is otherwise obscure today.

During the emperor's exile in Sichuan, Lü Yao and Zhu Qian were conferred crimson robes plus fish-pouch. They simultaneously received outer-court titles in two categories - a civil prestige title and a duty assignment:

Court Gentleman for Ceremonial Service (Rank 9a2),

Acting2 (shou) Assistant Magistrate of the Luo District of Han County (Rank 9a2-9b1).

將仕郎, 守漢州雒縣主簿

The second title is a nominal commission; these painters did not actually serve as Han County magistrates. As usual their quasi-official status is disclosed with a prefix, in this case “acting2” shou 守, which indicates that their rank was lower than appropriate for this title. Emperor Tang Xizong probably rewarded Lü Yao and Zhu Qian for their loyalty with a ranked, non-substantive duty assignment under the unexpected circumstances of the emperor's exile in Sichuan. During this extraordinary episode, a painter's allegiance was deemed deserving of recognition with an official rank and honors far beyond his existing inner-court Hanlin daizhao appointment.

From Lü Yao and Zhu Qian onwards, Hanlin daizhao became a title regularly held by painters. Just as significantly, their award served as a model for the Sichuanese practice of conferring nominal outer-court commissions and honorifics to the very top Hanlin daizhao painters. Going beyond this Tang model, the Shu kings then added the merit title as a painter's award category, and they apparently did this on account of two very special painters, namely Ruan Zhihui and Huang Quan. 


\section{Career advancement for Cheng Xiuji}

If the Shu kingdom awarded outer-court titles to painters more regularly after Lü Yao and Zhu Qian's examples, then the case of Cheng Xiuji adds further nuance to our above characterization of Tang precedent. Cheng's example provides a good foil to Lü and Zhu because Cheng did not regard himself as a professional painter. Cheng had literary ability and came from an educated family, yet he was recognized for his painting talent instead.

Zhu Jingxuan's 朱景玄 (fl. ca. 806-40), Tangchao minghualu 唐朝名畫錄 (Record of famous painters of the Tang dynasty) describes Cheng Xiuji as a direct pupil of celebrated figure painter Zhou Fang 周昉 (ca. 730-800) (Figure 2). Zhu reports that Cheng studied for twenty years with Zhou. For our purpose, this lineage is not as important as the fact that, according to Zhu, Cheng was the only person at Chang'an whose official career advanced based on his painting ability:

From the Zhenyuan era (785-805) on, he was the only individual in the capital who owed his advancement solely to his artistry as a painter and was continually graced by the imperial favor. ${ }^{18}$

貞元後, 以畫藝進身, 累承恩稱旨, 京都一人而已。

From his perspective as an art critic, Zhu Jingxuan brings our attention to the important idea that painting talent could serve as the basis for imperial favor in the 9th century. Yet our understanding of Cheng Xiuji is much enhanced by other surviving sources. Because he was a government officer, Cheng's biography is recorded in an epitaph; most painters do not have any epitaphic record. ${ }^{19}$ There is additionally an encomium mentioning Cheng composed by

18 Zhu Jingxuan 朱景玄, Tangchao minghualu 唐朝名畫錄 (Record of famous painters of the Tang dynasty), ca. 840s, in Lu Fusheng 盧輔聖 et al. Zhongguo shuhua quanshu 中國書畫全書 (Complete collected writings on Chinese calligraphy and painting), 10 vols. (Shanghai: Shanghai shuhua chubanshe, 1992-94), see vol. 1, page 167: “Miaopin zhong wu ren” 妙品中五人. Translation by Alexander C. Soper, “T’ang ch'ao ming hua lu. Celebrated Painters of the T'ang Dynasty by Chu Ching-hsüan of T’ang,” Artibus Asiae 21, 3/4 (1958), 204-30, see 223.

19 Zhou and Zhao, Tangdai muzhi huibian, vol. 2, 2398, “Tang gu Jixian zhi yuan guan Rong wangfu zhang shi Cheng gong muzhiming bing xu” 唐故集賢直院官榮王府長史程公墓誌銘並 敘. The epitaph notes that it was actually Cheng Xiuji's father, Cheng Yi 程儀, who studied with Zhou Fang. In any case, Cheng Xiuji eventually gained the favor of Emperor Tang Wenzong 文宗 (r. 826-40) for his well-researched illustrations of the Mao shi 毛詩 (Mao's edition of the Poetry Classic). 


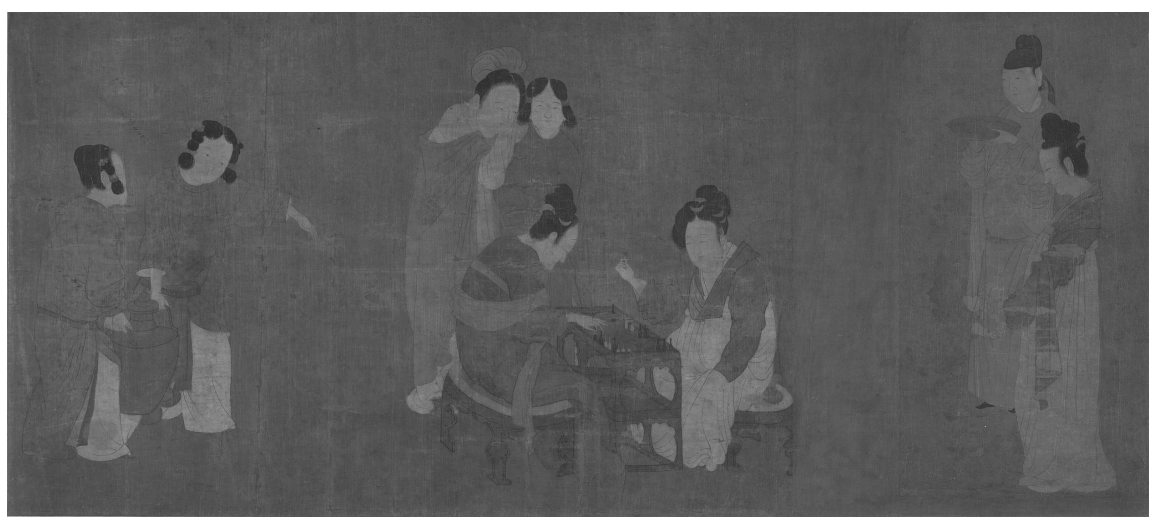

Figure 2: Traditionally attributed to Zhou Fang (傳)周昉 (ca. 730-ca. 800), Song dynasty. Palace Ladies Playing Double Sixes. Handscroll; ink and color on silk. Freer Gallery of Art, Smithsonian Institution, Washington, D.C., F1939.37 and F1960.4.

his contemporary, the famous poet $\mathrm{Du} \mathrm{Mu}$ 杜牧 (803-52). ${ }^{20}$ Together, these valuable descriptions provide us a much fuller picture than available for the careers of other mid-Tang painters.

Cheng Xiuji's family had enough history of office-holding for him to benefit from yin privilege. Cheng's epitaph confirms that he passed the imperial "Examination in Understanding the Classics” 應明經擢第 around 826 CE of the Baoli 寶曆 (825-27) era, after which he became eligible for appointment as an officer. Unusually, he then entered into the official hierarchy owing to his painting skills. The epitaph specifies that Cheng was appointed after the emperor's positive reaction to his illustrations of the Classics, specifically the images that he devised for the Maoshi 毛詩 (Mao's edition of the Poetry Classic). ${ }^{21}$

$20 \mathrm{Du} \mathrm{Mu}$ 杜牧, Fan Chuan wenji 㚞川文集, juan 19, “Zhang Youzhang, Cheng Xiuji chu zhu Wei jiangjun Hanlin daizhao deng zhi” 張幼彰程修已除諸衛將軍翰林待詔等製, in Wu Zaiqing 吳在慶, ed. Du Mu ji xi nian jiao zhu 杜牧集颣年校注 (Collected works of Du Mu with annotations and dates), Zhongguo gudian wenxue jiben congshu 中國古典文學基本叢, 4 vols. (Beijing: Zhonghua shuju, 2008), vol. 3, 1088-89 (Sibu congkan 四部叢刊, 14b-15a). For Wu Zaiqing's dating of Du Mu's encomium, see vol. 3, 1034-35, note 1. Cited by Li Wankang 李万康, ““Tang Cheng Xiuji muzhi” yu Cheng Xiuji shengping kaoshi” 唐程修已墓志与程修已生平考释, Meishu yu sheji 美术与设计 (Fine arts and design) 5 (2015): 40-46, esp. Part III, 42. I agree with Li Wankang's opinion that, "this is the only record of a Tang-dynasty court painter's official position and it has important historical value for understanding the Tang court's appointment and promotion system."

21 This epitaph received much attention in Chinese scholarship after its discovery in 1936. See Jin Weinuo 金维诺, “Wan Tang huajia Cheng Xiuji muzhi” 晚唐画家程修已墓志, Wenwu 文物 
Cheng Xiuji's official epitaph is invaluable as a supplement to the art texts. It is also noteworthy for the information that it omits. For example, the epitaph never mentions Cheng as a Zhou Fang student, and so differs from Zhu Jingxuan's description. Another omission from the epitaph is Cheng's promotion to Hanlin daizhao. Luckily this information is recorded in $\mathrm{Du} \mathrm{Mu}$ 's encomium, which is datable to 851/12 CE or early 852 CE. The information in Figure 3 showing Cheng's career chronology is based on these extant sources. ${ }^{22}$

\begin{tabular}{|c|c|c|}
\hline Dates & Career events & \\
\hline $825-27$ & Passed the Examination in Understanding the Classics & 應明經擢第 \\
\hline ca. $831-40$ & $\begin{array}{l}\text { Appointed Commandant of Fuliang (Rank 9b2), } \\
\text { with crimson robes plus fish-pouch ci-honors, } \\
\text { and [painter] on duty (zhi) at the Academy of Scholarly } \\
\text { Worthies. }\end{array}$ & $\begin{array}{l}\text { 授浮梁尉 } \\
\text { 賜緋魚袋 } \\
\text { 直集賢殿 }\end{array}$ \\
\hline 851 & $\begin{array}{l}\text { By decree, awarded the title Hanlin daizhao, } \\
\text { and Commandant for Glorifying the Martial (Rank 6a1). } \\
\text { Previously Acting2 (shou) Left General of the Courageous } \\
\text { Guard (Rank 3b), } \\
\text { Supreme Pillar of State (Rank 2a), } \\
\text { with purple robe plus gold fish-pouch ci-honors. }\end{array}$ & $\begin{array}{l}\text { 敕翰林待詔 } \\
\text { 昭武校尉 } \\
\text { 前守左驍衛將軍 } \\
\text { 上柱國 } \\
\text { 賜紫金魚袋 }\end{array}$ \\
\hline After 851 & $\begin{array}{l}\text { Additional promotion to Secretariat of the Heir Apparent } \\
\text { (Rank 5a1) }\end{array}$ & 累遷至太子中舍 \\
\hline 862 & $\begin{array}{l}\text { (In his 7th promotion) Administrator in a Princely } \\
\text { Establishment (Rank 4b1) }\end{array}$ & 凡七為王府長史 \\
\hline
\end{tabular}

Figure 3: Titles awarded to Cheng Xiuji 程修己 (804-63), military service official and painter.

4 (1963): 39-43; Niu Zhiping 牛志平, “Cheng Xiuji muzhi kaoshi” 程修已墓志考释, Wenbo 文 博 1 (1986): 51-53; Cen Zhongmian 岑仲勉, “Jinshi zheng shi: Cheng Xiuji muzhi ming” 金石证 史・程修己墓志铭, Jinshi lun cong 金石论从 (Beijing: Zhonghua shuju, 2004), 72-75; Zhu Guantian 朱关田, “Tang huajia Cheng Xiuji muzhi kaoshi” 唐画家程修已墓志考释, Chuguo ji: Zhu Guantian lun shu wenji 初果集 ·朱关田论书文集 (Beijing: Rongbao zhai chubanshe, 2008), 220-24; Hu Kexian 胡可先, ““Tang Cheng Xiuji muzhi” de wenben shidu yu jiazhi lun heng” 唐程修已墓志的文本释读与价值论衡, Zhongwen xueshu qian yan 中文学术前沿 2 (2011): 85.

22 Modifying Li Wankang, “Tang Cheng Xiuji muzhi,” Table 1, 43-44. See also pages 41-42 for discussion of Cheng Xiuji's duty as huazhi in the Academy of Scholarly Worthies. In contrast, Zhu Guantian, “Tang huajia Cheng Xiuji,” 222, proposes that Cheng’s first position was connected to the 834 CE promotion of his patron, Minister Chen Yixing 陳夷行 (d. 843). 
Cheng Xiuji's official career began around 831 CE upon recommendation by Minister Chen Yixing 丞相陳夷行 (d. 843; chief minister 837-39, 841-42), about five years after passing the examinations. Cheng's first personal rank was as Commandant of Fuliang 浮梁尉 (Rank 9b2), with ci-honors of crimson robes plus fish-pouch. The title was one of several belonging to Officers of the Imperial Guards 環衛官. ${ }^{23}$ Once referring to military units stationed at the capital as a defense force, they became largely decorative titles held by imperial family members and royal favorites, such as Cheng. He functioned as huazhi, serving as painter-on-duty at the Academy of Scholarly Worthies. These beginnings were followed by a major change in status when he gained access to the outercourt hierarchy with a nominal commission, the highest merit title, and higher $c i$-honors of purple robes plus gold fish-pouch. Presumably, this recognition resulted from the emperor's attention to Cheng's Maoshi illustrations.

Cheng Xiuji's new title sequence was as imperial bodyguard, prefixed "acting2," and thus followed the usual form to indicate that his advancement was fixed at a higher level than his actual rank:

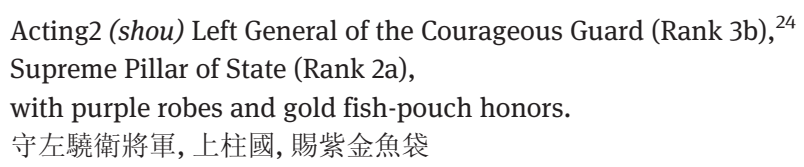

Cheng Xiuji remained at the above rank until $851 \mathrm{CE}$, when promoted again. Twenty years after first entering the service, Cheng now went up to Hanlin daizhao and also received the military prestige title of Commandant for Glorifying the Martial (Rank 6a1) 昭武校尉. In the subsequent decade, Chen continued to rise in rank through various palace affiliations. He was eventually appointed to the Heir Apparent's household and after that, from $862 \mathrm{CE}$, served one of the imperial sons (other than the Heir Apparent). The latter post offered Cheng his highest rank of $4 \mathrm{~b} 1$ before he passed away the very next year in $863 \mathrm{CE}$. At his death, he had served under four Tang emperors: Wenzong 文宗 (r. 826-40), Wuzong 武宗 (r. 840-46), Xuanzong 宣宗 (r. 846-59), and (Xizong’s father) Yizong 豇宗 (r. 859-73).

In sum, the epitaph paints a picture of an officer who was also a painter, downplaying his artistic talents. In contrast, Zhu Jingxuan's record - being primarily concerned with Cheng Xiuji's painting abilities - emphasized what Cheng's literary training brought to his images of classical and other subjects. While it is no surprise to find differing agendas between the two texts, putting them together provides a rare window into the dynamics between official rank and artistic

23 Hucker, Dictionary of Official Titles, 2830.

24 Gong Yanming, Songdai guanzhi, 433; Hucker, Dictionary of Official Titles, 2457. 
function and illustrates how a painter's inner-court and outer-court standings were negotiated. Cheng's social status, scholarly background, and creative talent were all factors affecting his career path. His case illuminates how the imperial city's bureaucracy positioned an incumbent's hierarchic location in nuanced ways and illustrates my argument that artist titles were not static - that they sometimes moved along an inner-court, outer-court structural continuum.

\section{Painting careers in a structural continuum}

Side by side, the careers of Tang painters Cheng Xiuji, Lü Yao, and Zhu Qian offer us insight into the problem of an artist's official recognition. Clearly our evaluations must be based on a range of factors rather than on any single title or moment in time. Cheng Xiuji began at a lowly Rank 9b2 as an Officer of the Imperial Guard, serving entry-level duty as a painter at the Academy of Scholarly Worthies. After a twenty-year career, he eventually achieved Rank 6a1 in the outer-court hierarchy with a military prestige title and raised as a painter to Hanlin daizhao. In his final decade of life, Cheng gained proximity to inner-court household agencies of the imperial establishment, reaching Rank 4b1 before death. Therefore, this thirty-year career trajectory moved along a classification continuum from inner-to-outer court, and then closer again to the inner court. His educational background and his artistic ability allowed him a measure of both inner- and outer-court recognition.

In comparison to officer Cheng Xiuji, much less is known about the professional painter Lü Yao, and Zhu Qian even less still. However, we are now aware that Lü and Zhu's careers reached a peak with a Rank 9b2 civil prestige title and Rank 9a2-9b1 nominal commission. They received these outer-court honorary or stipendiary titles during Emperor Tang Xizong's exile in Sichuan. Let us therefore describe Lü and Zhu's careers as illustrating inner-to-outer court movement.

All three painters were Hanlin daizhao who also held "acting" commissions. Cheng Xiuji's outer-court commission came with the highest merit title of Supreme Pillar of State, and with purple robes plus gold fish-pouch ci-honors. The titles represent a pivot point in his career, but they do not necessarily signify exceptional treatment since Cheng placed into official service as a member of the educated class. Such titles were commonly granted to officers in the military service hierarchy, and not out of step with regular appointment and promotion practices. Perhaps Cheng's example then opened the door for loyal subjects Lü Yao and Zhu Qian's special treatment. In contrast to Cheng, Lü and 
Zhu's titles were bestowed as ad hoc imperial favors rewarding their loyalty during dangerous times for their sovereign.

Top-tier Shu painters benefited from a process that originated in the 9th century with the three painters Cheng Xiuji, Lü Yao, and Zhu Qian - who in turned may have followed the titular example of 8th-century calligrapher Liu Qin. By the 10th century, Sichuan's painters received Hanlin daizhao and robes plus fish-pouch ci-honors with some regularity. A subset of five men received further outer-court recognition in their title sequences - the above discussed Ruan Zhihui, Huang Quan, their sons Ruan Weide and Huang Jucai, and Li Wencai. The five were awarded civil prestige titles and nominal commissions in the manner of Lü Yao and Zhu Qian. Ruan Zhihui and Huang Quan were the only two Sichuan natives given merit titles on top of their civil prestige titles and nominal commissions. Cheng Xiuji was perhaps the Tang-period model for this award, although in the Tang, painters were not offered merit titles; Cheng's merit title was based on his status as a military service official. It follows that the merit titles extended to Ruan Zhihui and Huang Quan was an innovation of the Shu kingdom on account of their two top painters. Indeed, the careers of Sichuan's elite painters exhibit various progressions in classification from inner-to-outer court, a feature that builds upon Tang precedent but exceeds it with a taller hierarchic structure.

\section{Conclusion}

Why did painters need court titles in Sichuan? To provide an answer, we must address why Shu rulers were motivated to combine inner and outer court awards to acknowledge their artistic ability and also offer them recognition in the official bureaucracy. It is not enough to describe such tactics as a ruler's prerogative to grant special treatment to certain individuals, or as a desire to exaggerate the ornamental effects of titles. While these factors are certainly at play, our reply must also take stock of the political dimensions of painters' collective memberships.

In the 10th century, the physically remote and historically independent southwestern Shu kingdom developed a unique system of titular awards that conceived of court painters in a hierarchy with several tiers. Some of these titles were similar to ones earlier held by 9th-century painters at the Tang dynasty's Hanlin Academy, and so they transmit Tang canonical court titles in Sichuan. The kings of Shu may have wished to preserve this aspect of Sichuan's Tang legacy - a legacy which arose after two Tang emperors took refuge in Sichuan while in exile. The Wangs and Mengs took up this powerful history and went 
further. By the mid-10th century, the Sichuanese had created several tiers of top painters based on Hanlin daizhao with and without stipendiary titles. They systematized rather uncommon Tang precedents to form the upper-level structure of a painter's institution. In fact, our attention to the spatial properties of titular categories not only clarified the career trajectories of 9th-century painters Cheng Xiuji, Lü Yao, and Zhu Qian, but also revealed this institutional innovation in 10th-century Sichuan.

The autonomous Shu kingdom certainly benefited from the prestige of copying Tang patterns of personnel administration, but clearly there existed circumstances in the 10th century that necessitated multiplying traditional offices. We discovered that Hanlin daizhao awards for painters increased in number, and the status of Sichuan's top painters was augmented with nominal commissions that embedded them into official hierarchies. While the artist titles examined above may be sinecures, they are far from meaningless. On the contrary, these titles defined court painters as inner court members with outer court recognition to display the authority of their art and activities. Indeed, painting culture was a distinguishing product of the Shu region, playing a central role in inter-kingdom trade and diplomacy. Painters received outer-court sinecures commensurate with the important role that their paintings played in functions of the state. Shu rulers were thus able to take advantage of the cultural capital that their patronage produced for cultivating relations with other southern kingdoms.

Besides political symbolism, diplomatic relations, and administrative expediency, one other reason to establish a formal system for recognizing painters was the value produced by hierarchy itself. Representing Shu painting families within an institutional structure added greatly to the value of Sichuan's family traditions, such as those represented by the talents of the Ruans and Huangs, and also the Changs 常, Zhaos 趙, Dus 杜, and Pus 蒲. In this way, the surnames of generations of Shu painters were established as part of Sichuan's cultural legacy, an inheritance materialized in the official record.

\section{References}

Bischoff, Friedrich Alexander, La forêt des pinceaux: Étude sur l'Académie du Han-lin sous la dynastie des T'ang et traduction du Han lin tche, Bibliothèque de l'Institut des hautes études chinoises 17 (Paris: Presses Universitaires de France, 1963).

Cen Zhongmian 岑仲勉, “Jinshi zheng shi: Cheng Xiuji muzhi ming” 金石证史 - 程修已墓志铭, Jinshi lun cong 金石论丛 (Beijing: Zhonghua shuju, 2004). 
Chen Zhongfu 陈仲夫 and Wang Su 王素 eds., Han-Tang zhiguan zhidu yanjiu 汉唐职官制度研 究 (Study of the official system in Han and Tang dynasties) (Beijing: Zhonghua shuju, 1993).

Du Mu 杜牧 (803-ca. 852), Fan Chuan wenji 㚞川文集 (Collected writings of Du Mu), 21 juan, in Wu Zaiqing 吳在慶, ed. Du Mu ji xi nian jiao zhu 杜牧集繫年校注 (Collected works of Du Mu with annotations and dates), Zhongguo gudian wenxue jiben congshu 中國古典文 學基本叢, 4 vols. (Beijing: Zhonghua shuju, 2008).

Foong Ping, "The Structural Position of Court Artists in the Song Dynasty: Issues of Rank, Title, and Legitimate Rule During the Founding Decades” 宋代宮廷畫家的官署機構, in Wu Hung, ed., Tenth-Century China and Beyond: Art and Visual Culture in a Multi-centered Age (Chicago: Center for the Art of East Asia, University of Chicago, and Art Media Resources, 2013), 350-63.

Foong Ping, "On rulers and painters: Issues of institutional patronage and transmitted hierarchies," conference paper for the panel, "National Committee on the History of Art State of the Field: New Frontiers in Chinese Art." College Art Association, 102nd Annual Conference, Chicago, 2014.

Foong Ping. "Representing Nation at the Painting Academy of Song Taizong," on the panel, "Song Taizong's Culture Revolution: The Transformation of Imperial Art, Literature, and Statecraft during the Late Tenth Century," Asia in Motion: Ideas, Institutions, Identities. AAS-in-ASIA, Academia Sinica, Taipei, Taiwan, 2015.

Gong Yanming 竟延明, Songdai guanzhi cidian 宋代官制辭典. (Dictionary of Song dynasty official titles) (Beijing: Zhonghua shuju, 1997).

Hartman, Charles, "Sung Government and Politics," in Chaffee, John W. and Denis Twitchett, eds., The Cambridge History of China, Volume 5, Part Two: Sung China, 960-1279 (Cambridge: Cambridge University Press, 2009), 19-138.

Hong Zun 洪遵 (1120-74), comp. Hanyuan qunshu 翰苑群書 (Collected writings on the Hanlin Institute), 12 juan (Beijing: Zhonghua shuju, 1991). HYQS.

Hong Zun 洪遵 (1120-74), Hanyuan yishi 翰苑遺事 (Incidents of past ages at the Hanlin Institute), in HYQS, 76-89.

Hu Kexian 胡可先, ““Tang Cheng Xiuji muzhi” de wenben shidu yu jiazhi lun heng” 唐程修已 墓志的文本释读与价值论衡, Zhongwen xueshu qian yan 中文学术前沿 2 (2011): 85.

Huang Xiufu 带休復 (b. ca. 954-959), Yizhou minghua lu 益州名畫錄 (Record of Famous Paintings in Yizhou) (short title YZMHL), in Huashi congshu 畫史叢書 (Collectanea of painting histories), 4 vols. (Taiwan: Wenshizhe chubanshe, 1983), vol. 3, 1375-1432.

Hucker, Charles O. A Dictionary of Official Titles in Imperial China (Stanford: Stanford University Press, 1998, first published 1985).

HYQS, see Hong Zun, Hanyuan qunshu.

Jin Weinuo 金维诺, “Wan Tang huajia Cheng Xiuji muzhi” 晚唐画家程修已墓志, Wenwu 文物 4 (1963): 39-43.

Li Jiebing 李潔冰 and Li Zhenggeng 李正庚, “Lun Tang dai shishu ji qi zhidu hua” 論唐代侍書 及其制度化, Xueshu jiaoliu 學術交流 4 (2008): 171-74.

Li Wankang 李万康, ““Tang Cheng Xiuji muzhi” yu Cheng Xiuji shengping kaoshi” 唐程修已墓 志与程修已生平考释, Meishu yu sheji 美术与设计 5 (2015): 40-46.

Li Wankang 李万康, “Tang dai Hanlinyuan hua daizhao renyong zhidu kao shu” 唐代翰林院画 待诏任用制度考述, Gugong bouwyuan yuankan 故宫博物院院刊 4 (2017): 46-57.

Lu Zengxiang 陆增祥, Baqiong shi jinshi buzheng 八琼室金石补正 (Beijing: Wenwu chubanshe, 1985). 
Mesnil, Evelyne, “Didactic Paintings between Power and Devotion: The Monastery Dashengcisi 大聖慈寺 in Chengdu (8th-10th c.)," in Christian Wittern and Shi Lishan eds., Essays on East Asian Religion and Culture: Festschrift in honour of Nishiwaki Tsuneki on the occasion of his 65th birthday (Kyoto: Editorial committee for the Festschrift in honor of Nishiwaki Tsuneki, 2007), 98-148.

Niu Zhiping 牛志平, “Cheng Xiuji muzhi kao shi” 程修已墓志考释, Wenbo 文博 1 (1986): 51-53.

Soper, Alexander C. "T'ang ch'ao ming hua lu. Celebrated Painters of the T'ang Dynasty by Chu Ching-hsüan of T'ang," Artibus Asiae 21, $3 / 4$ (1958), 204-230.

Wang Haibin 王海宾, Tang dai Hanlin shu daizhao zhidu zongkao 唐代翰林书待诏制度综考 (M.A. thesis, Jilin University, 2008).

Wang Yuanjun 王元军, “Tang dai de Hanlin shu daizhao ji qi huodong kao shu” 唐代的翰林书 待诏及其活动考述, Meishu yanjiu 美术研究 3 (2003): 100-104.

Wang Yuanjun 王元军. “Wan Tang yu nei gongfeng caoshu seng Bianguang shiji tantao”晚唐 御内供奉草书僧辩光事迹探讨, Zhongguo shufa 中国书法 2 (2005): 28-30.

Wei Zhiyi 韋執誼 (769-814), Hanlinyuan gushi 翰林院故事 (Stories of the Hanlin Institute), 786 CE, in HYQS, juan 4, 11-16.

Xie Baocheng, trans. Chen Mirong, A Brief History of the Official System in China (London: Paths International Ltd., and Social Sciences Academic Press, China, 2013).

YZMHL, see Huang Xiufu, Yizhou minghua lu.

Zhou Shaoliang 周紹良 and Zhao Chaofu 趙超副 eds., Tangdai muzhi huibian 唐代墓誌彙編 (Compilation of Tang dynasty epitaphs), 2 vols. (Shanghai: Shanghai guji chubanshe, 1992).

Zhu Guantian 朱关田, “Tang huajia Cheng Xiuji muzhi kaoshi” 唐画家程修己墓志考释, Chuguo ji: Zhu Guantian lun shu wenji 初果集·朱关田论书文集 (Beijing: Rongbao zhai chubanshe, 2008).

Zhu Jingxuan 朱景玄 (act. mid-9th c.), Tangchao minghua lu 唐朝名畫錄 (Record of famous painters of the Tang dynasty), ca. 840s, in Lu Fusheng 盧輔聖 et al. Zhongguo shuhua quanshu 中國書畫全書 (Complete collected writings on Chinese calligraphy and painting), 10 vols. (Shanghai: Shanghai shuhua chubanshe, 1992-94), vol. 1, 161-69. 